\title{
A Quaternary very young juvenile Tapirus Brisson, 1762 (Mammalia, Perissodactyla) from a cave deposit in northern Brazil: taxonomy and taphonomy
}

\author{
Germán Mariano Gasparini $^{\mathrm{a} *}$, Elizete Celestino Holanda ${ }^{\mathrm{b} 1}$, Hermínio Ismael de Araújo-Júnior ${ }^{\mathrm{c} 2}$ and \\ Leonardo dos Santos Avilla ${ }^{\mathrm{d} 3}$ \\ ${ }^{a}$ División Paleontología Vertebrados, Museo de La Plata, CONICET, Paseo del Bosque, s/n $n^{\circ}, 1900$ La Plata, Argentina; ${ }^{b}$ Laboratório de \\ Paleontologia da Amazonia, Departamento de Geologia, Universidade Federal de Roraima, Av. Cap. Ene Garcez, 2412, Aeroporto, Boa \\ Vista, Roraima, Brazil; ' Programa de Pós-graduação em Geologia, Departamento de Geologia, Instituto de Geociências, Universidade \\ Federal do Rio de Janeiro (UFRJ), Rio de Janeiro, Brazil; ${ }^{d}$ Laboratório de Mastozoologia, Departamento de Zoologia, Universidade \\ Federal do Estado do Rio de Janeiro (UNIRIO), Av. Pasteur 458, Sala 501, Urca 22290-240, Rio de Janeiro, Brazil
}

(Received 11 February 2015; accepted 25 March 2015)

\begin{abstract}
During fieldworks carried out from 2009 to 2013 in Aurora do Tocantins (northern Brazil), three isolated deciduous teeth of Tapirus were recovered. Those fossils come from a sedimentary deposit of presumed Late Pleistocene-early Holocene age in a karstic cave. This contribution aims to present a new locality of fossil Tapirus from northern Brazil, describe for the first time deciduous fossil teeth for South American Tapirus and evaluate the taphonomic aspects of those fossils. The specimens probably belong to the same individual due to there are no repeated teeth and they have the same wear pattern. Furthermore, the crowns of those teeth show no evidence of abrasion produced by transport. However, some abrasion is observed on the borders of the pulp chamber of teeth. These polishing are probably resulting of a very short transport (parautochthonous). These specimens are the only record of Tapiridae in Gruta do Urso cave; due to correspond to isolated and deciduous teeth, its identification to species level was not possible. There is not yet clear evidence that may indicate the kind of death of the individual studied here.
\end{abstract}

Keywords: Tapiridae; Tocantins State; morphology; morphometry; age estimation; South America

\section{Introduction}

Fossil tapirs (Tapiridae) are known from Europe, North America, Central America, South America and Southeastern Asia, including China (e.g. Cerdeño and Ginsburg 1988; Mc Kenna and Bell 1997; Eberle 2005; Hulbert 2005; Tong 2005; Ferrero and Noriega 2007; Holanda et al. 2011; Medici 2011, Scherler et al. 2011; Holanda and Ferrero 2013). Only Tapirus Brisson, 1762 represents the family in South America; evidence suggests that this genus migrated to South America from North America during the Great American Biotic Interchange (GABI; David Webb 2006; Woodburne et al. 2006; GABI 2 sensu Woodburne 2010). The oldest reliable record of the genus Tapirus is from the Early Pleistocene (ca.2.6-1.0 Ma) of the Pampean Region of Argentina (Tonni 1992), although there are hypotheses suggesting that tapirs entered in South America during the Late Miocene (Campbell et al. 2010).

The extant tapirs are represented by four Neotropical species - Tapirus bairdii (Gill, 1865); Tapirus pinchaque (Roulin, 1829); Tapirus kabomani Cozzuol, Clozato, Holanda, Rodrigues, Nienow, De Thoisy, Redondo and Santos, 2013 and Tapirus terrestris (Linnaeus, 1758) and a fifth species, Tapirus indicus Desmarest, 1819 from the Oriental hemisphere (Nowak 1997; Cozzuol et al. 2013).
Although remains of Tapirus are often fragmentary and scarce compared with other mammalian migrants that took part in the GABI, the fossil record of South American tapirs has substantially increased in quantity during the last years, and now comprises material from Argentina, Brazil, Peru, Uruguay, Bolivia and Venezuela (e.g. Rusconi 1928; Hoffstetter 1963; Takai et al. 1982, 1984; Ubilla 1983, 2004; Marshall et al. 1984; Hoffstetter 1986; Marshall and Sempere 1991; Tonni 1992; Ferrero and Noriega 2003, 2007; Holanda and Cozzuol 2006; Ferrero et al. 2007, 2009; Holanda et al. 2007, 2011; Ubilla and Rinderknech 2007; Holanda and Rincón 2009; Rincón et al. 2009, 2011; Gasparini et al. 2013; Ferrero et al. 2014).

According to Holanda and Ferrero (2013), the following extinct species of tapirs are recognised for South America: Tapirus mesopotamicus Ferrero and Noriega, 2007; Tapirus greslebini Rusconi, 1934; Tapirus rioplatensis Cattoi, 1957; Tapirus tarijensis Ameghino, 1902; Tapirus oliverasi Ubilla, 1983; Tapirus cristatellus Winge, 1906 and Tapirus rondoniensis Holanda, Ferigolo and Ribeiro, 2011.

During fieldworks carried out from 2009 to 2013 in the municipality of Aurora do Tocantins (State of Tocantins, northern Brazil, Figure 1), we recovered some isolated deciduous teeth of Tapirus from a sedimentary deposit of

*Corresponding author. Email: germanmgasparini@gmail.com 




Figure 1. Location of the palaeontological site. At the right top corner, the map of Brazil showing Tocantins State in grey, and the larger map shows Tocantins State in white, emphasising the study area $\left(12^{\circ} 35^{\prime} 0.08^{\prime \prime} \mathrm{S}\right.$ and $\left.46^{\circ} 30^{\prime} 58.39^{\prime \prime} \mathrm{W}\right)$.

presumed Late Pleistocene-early Holocene age in a karstic cave (see Section 3).

This contribution aims to present a new locality of fossil Tapirus from northern Brazil, describe for the first time deciduous fossil teeth for South American Tapirus and evaluate the taphonomic aspects of those fossils.

\section{Materials and methods}

Comparative materials used in morphometric analyses: Tapirus terrestris: MCP 1598; MCN 1315; MNRJ 1655, 64153, 64215, 71597; MZUSP 1598, 3232, 8482, 9600, 20032, 22421; UFMG 3142; UNIR-M 067, O83. Tapirus webbi: UF 1111, 11117, 26166, 26188, 26192, 26216, 27006, 211209, 211210, 211266; F: AMNH 37402.

Abbreviations: dpm3, deciduous third lower premolar; dpm4, deciduous fourth lower premolar; DPM4, deciduous fourth upper premolar.

Institutional abbreviations: F:AMNH, Frick fossil mammal collection, American Museum of Natural History, New York, USA; MCN, Museu de Ciências Naturais, Fundação Zoobotânica do Rio Grande do Sul, Porto Alegre, Brazil; MCP, Museu de Ciências of Pontiícia Universidade Católica do Rio Grande do Sul, Porto Alegre, Brazil; MNRJ, Museu Nacional do Rio de Janeiro, Rio de Janeiro, Brazil; MZUSP, Museu de Zoologia, 
Universidade de São Paulo, São Paulo, Brazil; UF, Florida Museum of Natural History, Gainesville, USA; UFMG, Coleção de Mastozoologia, Universidade Federal de Minas Gerais, Belo Horizonte, Brazil; UNIR-M, Universidade Federal de Rondônia, Mastozoología, Porto Velho, Brazil; UNIRIO-PM, paleontological collection of Laboratório de Mastozoologia, Universidade Federal do Estado do Rio de Janeiro, Brazil.

Measurements were taken using Vernier callipers, with $0.01 \mathrm{~mm}$ accuracy; data are expressed in millimetres. Whenever possible, morphometric analyses were performed using version $2.17 \mathrm{c}$ of the Paleontological Statistics - PAST software (Hammer et al. 2001). All measurements were $\log 10$ transformed before analysis.

We have followed the taxonomical arrangement proposed by Holanda and Ferrero (2013) because this is the most current integrative review of the South American Tapiridae.

We could only compare the specimens studied here to Tapirus terrestris because all South American fossil species do not have deciduous teeth preserved and also there are no morphological differences in deciduous dentition among the other extant species, except in the DPM1-2 (Simpson 1945; Holanda et al. 2011).

The following taphonomic aspects were evaluated: abrasion, bone representativeness and sorting. Such aspects were identified and interpreted according to Shipman (1981), Behrensmeyer (1991), Lyman (1994) and Holz and Simões (2002). The terms autochthonous, parautochthonous and allochthonous are according to the definitions of Behrensmeyer and Hook (1992): autochthonous, a non-transported fossil assemblage; parautochthonous, a transported fossil assemblage, but preserved within its habitat area and allochthonous, fossil assemblage transported and preserved outside its habitat area.

\section{Location, geological setting and age}

The fossils described here were collected in 2009 and 2013 from the Gruta do Urso limestone cave in the municipality of Aurora do Tocantins $\left(12^{\circ} 35^{\prime} 0.08^{\prime \prime} \mathrm{S}\right.$ and $\left.46^{\circ} 30^{\prime} 58.39^{\prime \prime} \mathrm{W}\right)$, State of Tocantins, northern Brazil (Figure 1). The geological context of the study area is still poorly understood. Online notes of Companhia de Pesquisa de Recursos Minerais (2006) on the geology of this municipality report carbonate and terrigenous deposits of the Bambuí Group, which is Neoproterozoic in age. In order to recognise stratigraphic aspects, a controlled excavation in the cave was conducted and three levels were recognised. A superficial carbonated layer cemented the top of the cave deposit, and this limited the top of the fossil bearing layer. This fossiliferous level has a thickness of around $180-220 \mathrm{~mm}$, and it is composed of laminated reddish-grey loess-like sediments of granulometry from very thin to thin. The bottom of the fossil bed is limited by a non-fossiliferous yellowish layer with thicker granulometry.

Although there is no absolute dating for the fossils described here, their age can be discussed based on dates from the bottom and top of the fossiliferous level and also by the faunistic assemblage found associated at that same level. Nevertheless, fossils of Panthera onca (Linnaeus, 1758) found at the bottom and Morenelaphus Carette, 1922 from the top of the fossiliferous level gave dates of around 22,000 and 3800 electron spin resonance years BP, respectively (Pegô et al., in prep.; Rodrigues et al. 2014). In addition, the Tapirus fossils from Gruta do Urso cave were found in association with the armadillo Propraopus sulcatus (Lund, 1842), which is restricted to the Early Pleistocene-Late Pleistocene (Castro et al. 2013) and, also to the equid Equus (Amerhippus) neogeus Lund, 1840, which is a fossil guide for the Lujanian (Late Pleistoceneearly Holocene; Cione and Tonni 1999, 2005). Meanwhile, the Tapiridae fossils here studied can be attributed to the Late Pleistocene-early Holocene.

\section{Systematic palaeontology}

Class Mammalia Linnaeus, 1758

Order Perissodactyla Owen, 1848

Family Tapiridae Burnett, 1830

Genus Tapirus Brisson, 1762

Tapirus sp

\subsection{Chronological and geographic distribution in South America}

Currently, it is found from Rio Grande do Sul, Brazil, and the Gran Chaco of Argentina and Paraguay, until the west of the Andes, from the northern portion of Colombia to the Gulf of Guayaquil in Ecuador (Brooks et al. 1997). However, in the Late Pleistocene, it is recorded until Uruguay (Ubilla 1996) and the Province of Entre Ríos, Argentina (Tonni 1992; Ferrero et al. 2007), about $32^{\circ} \mathrm{S}$ (Arroyo Perucho Verna paleontological site, Colón Department; Figure 2).

The oldest assured record of the genus Tapirus in South America is from the Early Pleistocene of Argentina (Tonni 1992).

\subsection{Studied material}

Isolated teeth: DPM4 left (UNIRIO-PM 1340), dpm3 right (UNIRIO-PM 1342) and dpm4 right (UNIRIO-PM 1341), all deciduous teeth (Figure 3 ).

\subsection{Geographical and stratigraphical provenance}

The fossil material comes from the Gruta do Urso cave, State of Tocantins, Brazil (Figure 1). Age: Late Pleistocene/ early Holocene. 


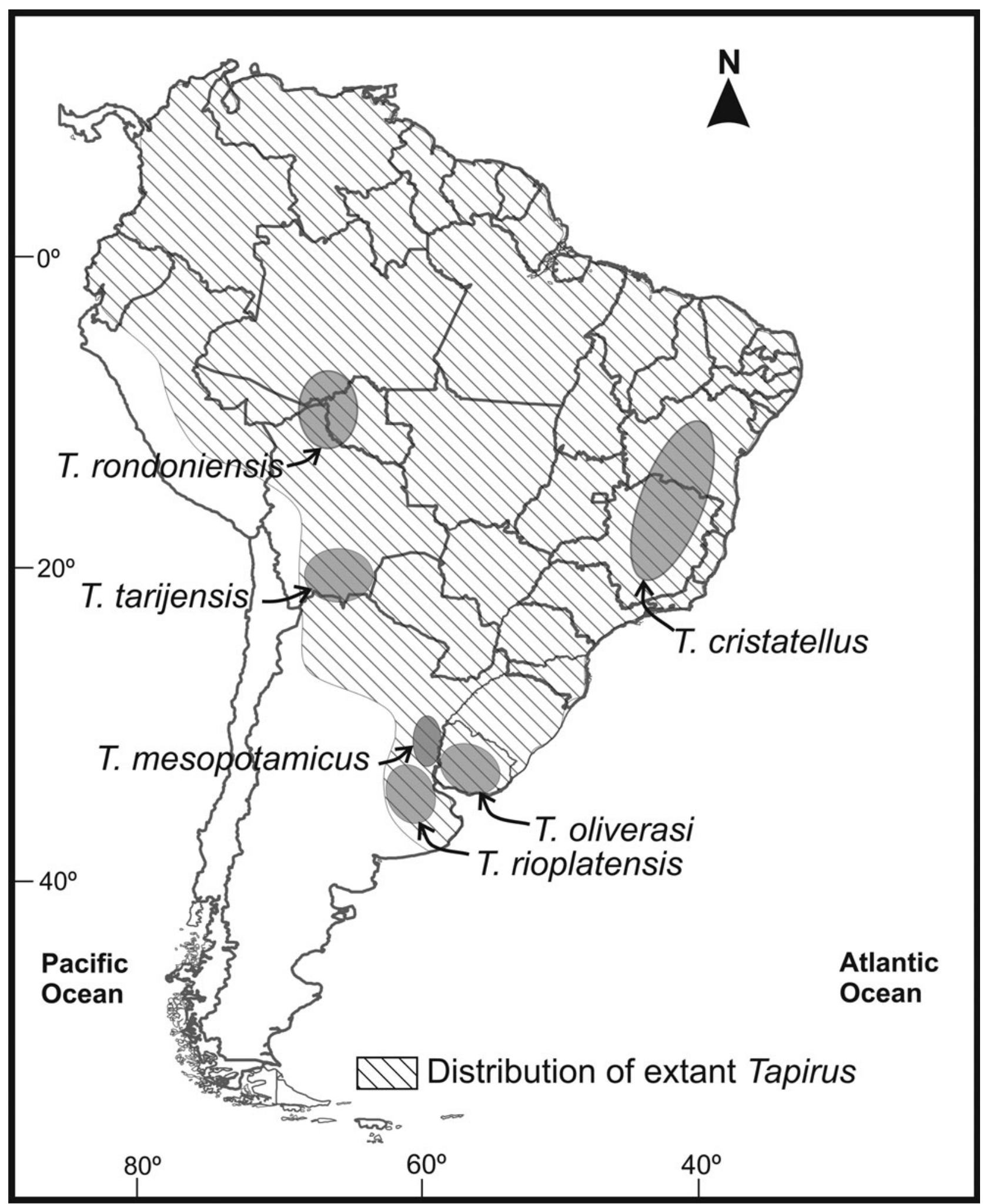

Figure 2. Geographical distribution of fossil species of the genus Tapirus for the Quaternary of South America. Mistribution of extant Tapirus. 


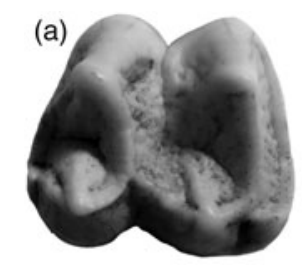

(b)

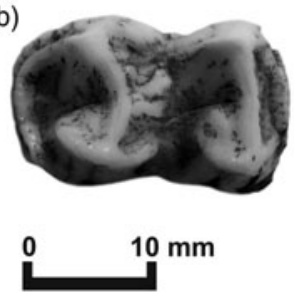

(c)

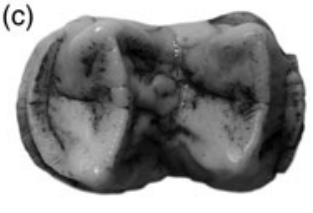

Figure 3. Occlusal view of studied material. (a) DPM4 left (UNIRIO-PM 1340), (b) dpm3 right (UNIRIO-PM 1342) and (c) dpm4 right (UNIRIO-PM 1341). Scale bar $=10 \mathrm{~mm}$.

\subsection{Description}

The crown morphology of the material herein studied is lophodont and the crown height is taller than a typical brachyodont.

DPM4 (UNIRIO-PM 1340): The outline of this tooth is quadrangular in occlusal view (Figure 3(a)). This tooth has a strong parastyle developed; parastyle height is more than $50 \%$ of paracone height, but the parastyle is smaller than paracone. The parastyle is separated from the paracone by a buccal ridge. The protocone and hypocone are widely separated, but the paracone and metacone are united forming a pronounced longitudinal crest (ectoloph). The protoloph is wider than the metaloph; they are separated lingually by a transverse groove, and both are oriented transversely. The mesial and distal cingula are well developed; the labial one on the posterior half and lingual cingulum are absent.

dpm3 (UNIRIO-PM 1342): The outline of this deciduous tooth is rectangular in occlusal view (Figure 3 (b)). The protolophid and hypolophid are approximately equal in height and are well separated each other. Mesial and distal cingula are well developed, but no labial or lingual cingulids are present.

dpm4 (UNIRIO-PM 1341): The outline of this deciduous tooth is rectangular in occlusal view (Figure 3 (c)). The protolophid and hypolophid are approximately equal in height and are well separated each other. Mesial and distal cingula are well developed, but no labial or lingual cingulids are present. Both dpm3 and dpm4 lacking accessory cuspids and metastylids.

Measurements: DPM4: length $21.46 \mathrm{~mm} \times$ width $19.29 \mathrm{~mm}$; dpm3: length $22.54 \mathrm{~mm} \times$ width $14.93 \mathrm{~mm}$; dpm4: length $23.43 \mathrm{~mm} \times$ width $14.81 \mathrm{~mm}$.

\subsection{Remarks: age estimation}

All teeth recovered from Gruta do Urso cave are deciduous premolars. A detailed analysis of crown enamel of those Tapirus sp. teeth in a stereomicroscope shows that all have no wear. Hulbert et al. (2009) proposed an age group classification for Tapirus based on gross dental wear, and accordingly, all fossils recovered from Gruta do Urso cave representing very young juveniles. Moreover, dental wear keys developed by Maffei (2003) and Hitchins (1978) were used to attribute 'calendar' ages to individuals of Tapirus polkensis (a North American fossil tapir) that exhibit similar amounts of wear. Therefore, all Tapirus fossils studied here are classified in group 0 (zero), deciduous premolars with little to no wear. Furthermore, Gibson (2011) combined the age group of Hulbert et al. (2009), the 'calendar' age of Maffei (2003) and Hitchins (1978) and direct analysis of Tapirus bairdii (the extant Central American Tapir) specimens in US zoos, and proposed a dental wear key for placing tapirs into rough age groups. Based on that, the Tapirus specimens from Gruta do Urso cave were under 1 year old when they died. Furthermore, the absence of dental wear on the specimens suggests that the individual died around a few days from its birth because around 10 days the calf actively follows the mother through the forest (Wilson and Mittermeier 2011) experiencing solid foods (abrasive) other than milk. Thus, we consider the Tapirus fossils recovered from Gruta do Urso cave as belonging to a very young individual.

\subsection{Taphonomy}

The three specimens were found isolated, but they were found very close to each other. Furthermore, as there are no repeated teeth, the value of minimum number of individuals is one, and the three specimens have the same wear pattern (no wear). For all those reasons, we assume that the three specimens belong to the same individual.

The crowns of the teeth show no evidence of abrasion produced by transport or trampling. However, some abrasion is observed on the borders of the pulp chamber of teeth. These polishing can indicate a very short-distance transport of the specimens towards the cave, allowing the classification of the assemblage as parautochthonous (sensu Behrensmeyer and Hook 1992).

During the last 5 years, a great amount of mammalian fossils has been recovered from Gruta do Urso cave. Several mammalian groups were already identified in this assemblage (Avilla et al. 2013; Castro et al. 2013; Rodriguez et al. 2013; Rodrigues et al. 2014); however, the three isolated teeth presented here are the only record of 
tapirs. This intriguing representation of specimens can be associated to a sorting towards the more resistant specimens (teeth) face to destructive taphonomic processes, such as transport and weathering (Lyman 1994). Furthermore, if our estimative of age of the individual is correct, a very young animal would have most of its skeleton very fragile with lots of non-fused bones and cartilage components. In consequence, even if there was a very-short transport, most of the very young tapir carcass can have been destroyed before its deposition in the Gruta do Urso cave; otherwise we would find other cranial and post-cranial elements inside the cave.

According to Wilson and Mittermeier (2011), mortality in tapirs may be heavy during the first year of life due to predation. However, starvation or diseases can also be erected as causes of death of young individuals (Holz and Simões 2002). The assignment to the type of death could be made if post-cranial specimens of Tapirus had been found in Gruta do Urso cave because evidence of predation, disease or starvation is often observed in postcranial bones. Thus, only new findings including postcranial elements of Tapirus in Gruta do Urso cave will allow an assignment for the type of death more decisively.

\subsection{Morphology and morphometry}

Recently, studies have supported the high degree of morphological resemblance of the teeth of different species of Tapirus from South America (Perini et al. 2011; Holanda and Ferrero 2013; Ferrero et al. 2014). This morphological homogeneity has posed considerable problems for the definition of diagnostic characters, and thus also the assignment of fossil specimens to any particular species. On the other hand, tooth size differences have been used to distinguish between fossil species similar in size to Tapirus terrestris and larger than Tapirus terrestris, like Tapirus tarijensis, Tapirus greslebini, Tapirus oliverasi, Tapirus rioplatensis and, in some cases, Tapirus cristatellus (Holanda and Ferrero 2013; Ferrero et al. 2014).

The species Tapirus mesopotamicus and Tapirus rondoniensis were established based on cranial and upper teeth characters. Despite Tapirus oliverasi has been described based on a fragmented dentary, this species has larger size and robustness than Tapirus terrestris (Holanda and Ferrero 2013). In addition, Tapirus cristatellus was founded based on cranial characters, but taking into account its size, it is revealed an overlapping in some dimensions with Tapirus terrestris, but also it is larger than Tapirus terrestris in other measurements (Holanda et al. 2012; Holanda and Rincón 2012).

The specimens of Gruta do Urso cave share the common deciduous teeth characters with Tapirus terrestris (Simpson, 1945). However, differences in deciduous teeth to the other South American fossil species are unknown, except for the dpm 2 from Tapirus tarijensis (Ferrero et al. 2014). Regarding the size, the measurements of Gruta do Urso cave specimens were compared with Tapirus terrestris and Tapirus webbi (large North American fossil tapir). The results were controversial. The principal component analyses of dpm3 and dpm4 measurements (Figure 4(a)) show a distinction between Tapirus terrestris and Tapirus webbi and also a slight overlap along PC2. UNIRIO-PM 1342 and UNIRIO-PM 1341 fell within the larger size range of Tapirus webbi in this case. However, the length and width ratio of UNIRIO-PM 1340 (Figure 4 (b)) showed the width of DMP4 is less than Tapirus terrestris and Tapirus webbi, and the length of DPM4 is within size range of Tapirus terrestris. Because the ontogenetic and taphonomic analysis suggest that the teeth belong to the same individual, this variation in size do not


Figure 4. Morphometric analysis. (a) Scatter plot of the first two principal component scores arising from the PCA of de dpm3 and dpm4 measurements and (b) Scatter plot of the width and length of DPM4. Percentage (\%) of variation explained. 
allow us to assign them to a particular species. Perini et al. (2011) verified that size and proportions of lower molars are insufficient parameters to describe and identify fossil species of Tapirus. For those deciduous teeth from Gruta do Urso cave, the sample size also did not allow us to make a statistically significant analysis.

\section{Conclusion}

The three specimens belonging to the same individual of Tapirus sp. are described for Gruta do Urso cave fossil assemblage. Some minor evidence of abrasion was observed on the borders of the pulp chamber of teeth, allowing us to infer that the specimens were transported through a short distance and, therefore, represent parautochthonous elements.

These specimens are the only record of Tapiridae in Gruta do Urso cave; due to correspond to isolated and deciduous teeth, its identification to species level is not possible. If our estimative of age of the individual represented by the three deciduous teeth is correct, a very young animal would have most of its skeleton very fragile with lots of non-fused bones and cartilage components. In consequence, even if there was a very short transport, most of the very young tapir carcass should be destroyed before its deposition in the Gruta do Urso cave. Only new findings including post-cranial elements of Tapirus in Gruta do Urso cave will allow an assignment of the type of death more decisively.

\section{Acknowledgements}

The authors thank Alejandro G. Kramarz (MACN), C. Cartelle (PUC-Minas), I. Olivares (MLP) for access to material under their care. We extend our acknowledgements to W. de Moura and the Municipality of Aurora do Tocantins for supporting logistically all the fieldtrips. Anonymous referees and Editor (G. Dyke) helped to improve the manuscript.

\section{Disclosure statement}

No potential conflict of interest was reported by the authors.

\section{Funding}

The field trips, which resulted in the collection of the specimen, were made possible by the financial support of the Universidade Federal do Estado do Rio de Janeiro (UNIRIO), Conselho Nacional de Desenvolvimento Científico e Tecnológico [grant number 401812/2010-3] (Edital MCT/CNPq no. 32/2010 Fortalecimento da Paleontologia Nacional/Edital 32/2010) and the UNIRIO. Also, this study was partially funded by the Fundação Carlos Chagas de Amparo à Pesquisa do Estado do Rio de Janeiro and Conselho Nacional de Desenvolvimento Científico e Tecnológico (CNPq), Brazil, and by the Consejo Nacional de Investigaciones Científicas y Técnicas and the PICT 2010-0804.

\section{Notes}

1. Email: elizete.holanda@gmail.com

2. Email: herminio.ismael@yahoo.com.br

3. Email: leonardo.avilla@gmail.com

\section{References}

Ameghino CF. 1902. Notas sobre algunos mamíferos fósiles nuevos o poco conocidos del Valle de Tarija [Notes on some new fossil mammals or little known from the Tarija Valley]. Ann Mus Nac Hist Nat Buenos Aires. 3:225-261.

Avilla LS, Müller L, Gasparini GM, Soibelzon L, Absolon B, Bonissoni Pêgo F, Silva RC, Kinoshita A, Baffa O, Graciano Figueiredo AM. 2013. The northernmost record of Catagonus stenocephalus (Lund in Reinhardt, 1880) (Mammalia, Cetartiodactyla) and its palaeoenvironmental and palaeobiogeographical significance. J S Am Earth Sci. 42:39-46. doi:10.1016/j.jsames.2012.10.001.

Behrensmeyer AK. 1991. Terrestrial vertebrate accumulations. In: Allison PA, Briggs DEG, editors. Taphonomy: releasing the data locked in the fossil record. New York, NY: Plenum Press; p. 291-335.

Behrensmeyer AK, Hook RW. 1992. Paleoenvironmental contexts and taphonomic modes. In: Behrensmeyer AK, Damuth JD, DiMichele WA, Potts R, Sues HD, Wing SL, editors. Terrestrial ecosystems through time: evolutionary paleoecology of terrestrial plants and animals. Chicago, IL: University of Chicago Press; p. 15-136.

Brooks DM, Bodmer RE, Matola S. 1997. Tapirs - Status survey and conservation action plan. Gland, Switzerland and Cambridge, UK: IUCN/SSC Tapir Specialist Group. 164 p.

Brisson MJ. 1762. Regnum animale in classes IX. distributum, sive synopsis methodica sistens generalem animalium distributionem in classes IX, and duarum primarum classium, quadrupedum scilicet and cetaceorum, particularem divisionem in ordines, sectiones, genera and species. Cum brevi cujusque speciei descriptione, citationibus auctorum de iis tractantium, nominibus eis ab ipsis and nationibus impositis, nominibusque vulgaribus. Editio altera auctior. Lugduni Batavorum. 1-7:1-296.

Burnett GT. 1830. Illustrations of the Quadrupeda, or quadrupeds, being the arrangement of the true four-footed beasts, indicated in outline. Quat J Scient Lit Arts. 26:336-353.

Campbell, Jr, KE, Prothero DR, Romero-Pittman L, Hertel F, Rivera N. 2010. Amazonian magnetostratigraphy: dating the first pulse of the Great American Faunal Interchange. J South Am Earth Sci. 29(3): 619-626. doi:10.1016/j.jsames.2009.11.007.

Castro MC, Avilla LS, Freitas ML, Carlini AA. 2013. The armadillo Propraopus sulcatus (Mammalia: Xenarthra) from the late Quaternary of northern Brazil and a revised synonymy with Propraopus grandis. Quat Int. 317:80-87. doi:10.1016/j.quaint.2013.04.032.

Cattoi N. 1957. Una especie extinguida de Tapirus Brisson (T. rioplantensis nov. sp.) [An extinct species of Tapirus Brisson (T. rioplatensis nov. sp.)]. Ameghiniana. 1:15-21.

Cerdeño E, Ginsburg L. 1988. Les Tapiridae (Perissodactyla, Mammalia) de l'Oligocène et du Miocène infèrieur europèens [The Tapiridae (Perissodactyla, Mammalia) from the Oligocene and early Miocene of Europe]. Ann Paléontol. 74:71-96.

Cione AL, Tonni EP. 1999. Biostratigraphy and chronological scale of uppermost Cenozoic in the Pampean area, Argentina [Biostratigraphy based on Upper Cenozoic mammals of Buenos Aires Province, Argentina]. In: Tonni EP, Cione AL (eds.), Quaternary vertebrate palaeontology in South America. Quat South Am Antarctic Peninsula. 12:23-52.

Cione AL, Tonni EP. 2005. Bioestratigrafía basada en mamíferos del Cenozoico Superior de la Provincia de Buenos Aires, Argentina. In: Barrio RE, Etcheverry RO, Caballé MF, Llambias E, editors. Geología y Recursos Minerales de la Provincia de Buenos Aires. La Plata: Quick Press; p. 183-200.

Companhia de Pesquisa de Recursos Minerais (CPRM) 2006. Rochas Carbonáticas do Grupo Bambuí na região Nordeste do Estado de Goiás. [cited 2010 Dec 5]. Available from: http://www.cprm.gov.br/ publique $/ \mathrm{cgi} /$ cgilua.exe/sys/start.htm?infoid=261\&sid=32 
Cozzuol MA, Clozato CL, Holanda EC, Rodrigues FHG, Nienow S, De Thoisy B, Redondo RAF, Santos FR. 2013. A new species of tapir from the Amazon. J Mammal. 94(6):1331-1345. doi:10.1644/12MAMM-A-169.1.

David Webb SD. 2006. The Great American Biotic Interchange: patterns and processes 1. Ann Missouri Bot Garden. 93(2):245-257. doi:10. 3417/0026-6493(2006)93[245:TGABIP]2.0.CO;2.

Desmarest AG. 1819. Nouveau dictionnaire d'histoire naturelle, appliquèe aux art, principalement à l'agriculture et à l'economie rurale et domestique; par une société de naturalistes. Nouvelle edition, presqu' entierement refondue et considerablement augmentee. Deterville, Paris, France.

Eberle JJ. 2005. A new 'tapir' from Ellesmere Island, Arctic Canada implications for northern high latitude palaeobiogeography and tapir palaeobiology. Palaeogeogr Palaeoclimatol Palaeoecol. 227(4): 311-322. doi:10.1016/j.palaeo.2005.06.008.

Ferrero BS, Brandoni D, Noriega JI, Carlini AA. 2007. Mamíferos de la Formación El Palmar (Pleistoceno tardío) de la provincia de Entre Ríos, Argentina [Mammals from El Palmar Formation (Late Pleistocene) at Entre Ríos Province, Argentina]. Rev Mus Arg Cienc Nat Bernardino Rivadavia. 9(2):109-117.

Ferrero BS, Gasparini GM, Soibelzon E, Zurita AE, Miño Boilini AR, Soibelzon L. 2009. Los tapires (Perissodactyla, Tapiridae) del Valle de Tarija, Bolivia. Consideraciones morfométricas e implicancias taxonómicas [The tapirs (Perissodactyla, Tapiridae) from Tarija Valley, Bolivia. Morphometric considerations and taxonomic implicances]. Ameghiniana Suplement. 46(4):77-78.

Ferrero BS, Noriega JI. 2003. El registro fósil de los tapires (Perissodactyla: Tapiridae) en el Pleistoceno de Entre Ríos [The fossil record of tapirs (Perissodactyla: Tapiridae) in the Pleistocene of Entre Ríos]. Ameghiniana. 40(4):84.

Ferrero BS, Noriega JI. 2007. A new upper Pleistocene tapir from Argentina: remarks on the phylogenetics and diversification of Neotropical Tapiridae. J Vert Paleontol. 27(2):504-511. doi:10. 1671/0272-4634(2007)27[504:ANUPTF]2.0.CO;2.

Ferrero BS, Soibelzon E, Holanda EC, Gasparini GM, Zurita AE, MiñoBoilini AR. 2014. A taxonomic and biogeographic review of the fossil tapirs from Bolivia. Acta Palaeontol Pol. 59(3):505-516.

Gasparini GM, Avilla LS, Machado H, Goñi DM. 2013. Los perisodáctilos (Tapiridae Burnett, 1830 y Equidae Gray, 1821) del Pleistoceno tardío del estado de Tocantins, norte de Brasil [The perisodactyls (Tapiridae Burnett, 1830 and Equidae Gray, 1821) from Late Pleistocene at Tocantins State, northern Brazil]. Ameghiniana Suplement. 50(6):50.

Gibson ML. 2011. Population structure based on age-class distribution of Tapirus polkensis from the Gray Fossil Site Tennessee. Electronic Theses and Dissertations. Paper 1267; [cited 2014 Mar 4]. Available from: http://dc.etsu.edu/etd/1267

Gill TN. 1865. Description of the genus Elasmognathus. Proc Acad Nat Sci Phila. 17:1-183.

Hammer O, Harper DAT, Ryan PD. 2001. PAST: paleontological statistics software package for education and data analysis. Palaeontol Electron. 4:1-9.

Hitchins PM. 1978. Age determination of the black rhinoceros (Diceros bicornis Linn.) in Zululand. S Afr J Wildlife Res. 8:71-80.

Hoffstetter R. 1963. La faune pléistocéne de Tarija (Bolivie) [The Pleistocene fauna of Tarija (Bolivia)]. Bull Mus Nat Hist Nat. 35: 194-203.

Hoffstetter R. 1986. High Andean mammalian faunas during the PlioPleistocene. In: Vuilleumier F, Monasterio M, editors. High altitude tropical biogeography. New York, NY: Oxford University Press; p. $218-245$.

Holanda EC, Cozzuol MA. 2006. New records of Tapirus from the late Pleistocene of southwestern Amazonia, Brazil. Rev Bras Paleontol. 9(2):193-200. Available from: http://dx.doi.org/10.4072/rbp.2006.2. 0310.4072/rbp.2006.2.03.

Holanda EC, Ferigolo J, Cartelle C. 2007. Novas considerações sobre a espécie Tapirus cristatellus Winge (Mammalia, Perissodactyla), Pleistoceno superior, Estado da Bahia, Brasil [New considerations about Tapirus cristatellus Winge (Mammalia, Perissodactyla), Late Pleistocene, Bahía State, Brazil]. Ameghiniana Suplement. 44(4):23.

Holanda EC, Ferigolo J, Ribeiro AM. 2011. New Tapirus species (Mammalia: Perissodactyla: Tapiridae) from the upper Pleistocene of
Amazonia, Brazil. J Mammal. 92(1):111-120. Available from:http:// dx.doi.org/10.1644/10-MAMM-A-144.110.1644/10-MAMM-A144.1.

Holanda EC, Ferrero BS. 2013. Reappraisal of the genus Tapirus (Perissodactyla, Tapiridae): systematics and phylogenetic affinities of the South American tapirs. J Mammal Evol. 20(1):33-44. doi:10. 1007/s10914-012-9196-z.

Holanda EC, Rincón AD. 2009. El registro fósil de los tapires (Mammalia: Perissodactyla) de Venezuela [The fossil record of tapirs (Mammalia: Perissodactyla) from Venezuela]. Paper presented at: XXIV Jornadas Argentinas de Paleontología de Vertebrados, San Rafael, Mendoza, Argentina. p. 38-39.

Holanda EC, Rincón AD. 2012. Tapirs from the Pleistocene of Venezuela. Acta Palaeontol Pol. 57(3):463-473. doi:10.4202/app. 2011.0001.

Holanda EC, Ribeiro AM, Ferigolo J. 2012. New material of Tapirus (Perissodactyla: Tapiridae) from the Pleistocene of southern Brazil. Rev Mex Cienc Geol. 29:308-318.

Holz M, Simões MG. 2002. Elementos Fundamentais de Tafonomia [Fundamental elements of Taphonomy]. Editora da Universidade/ UFRGS, Porto Alegre.

Hulbert, Jr, RC. 2005. Late Miocene Tapirus (Mammalia, Perissodactyla) from Florida, with description of a new species, Tapirus webbi. Bull Fla Mus Nat Hist. 45:465-494.

Hulbert, Jr, RC, Wallace SC, Klippel WE, Parmalee PW. 2009. Cranial morphology and systematics of an extraordinary sample of the late Neogene dwarf tapir, Tapirus polkensis (Olsen). J Paleontol. 83(2): 238-262. doi:10.1666/08-062.1.

Linnaeus C. 1758. Systema naturae per regna tria naturae [Natural System through the three natural kingdoms]. Animal Kingdom. 10th Edition. Holmiae, Stockholm, Sweden: L. Salvii. 4(1):1-824.

Lyman RL. 1994. Vertebrate taphonomy. Cambridge: Cambridge University Press.

Maffei L. 2003. The age structure of Tapirs (Tapirus terrestris) in the Chaco. Newslett IUCN/SSC Tapir Spec Group. 12(2):18-19.

Marshall LG, Berta A, Hoffstetter R, Pascual R, Reig OA, Bombin M, Mones A. 1984. Mammals and stratigraphy: geochronology of the continental mammal bearing quaternary of South America. Palaeovert Mém Extraord. 1-76.

Marshall LG, Sempere T. 1991. The Eocene to Pleistocene vertebrates of Bolivia and their stratigraphic context: a review. In: Suarez-Soruco R, editor. Fósiles y Facies de Bolivia. Volume I Vertebrados. Vol. 12. Santa Cruz, Bolivia: Revista Técnica de YPFB. p. 631-652.

Mc Kenna MC, Bell SK. 1997. Classification of mammals. Above the species level. New York, NY: Columbia University Press.

Medici EP. 2011. Family Tapiridae (Tapirs). In: Wilson DE, Mittermeier RA, editors. Handbook of the mammals of the world - Hoofed mammals. Barcelona: Lynx Editions. 2: 182-204.

Nowak RM. 1997. Walker's mammals of the world on-line 5.1. Baltimore, MD: Johns Hopkins University Press.

Owen R. 1848. Description of teeth and portions of jaws of two extinct anthracotheroid quadrupeds (Hyopotamus vectianus and hyopbovinus) discovered by the Marchioness of Hastings in the Eocene deposits on the N.W. coast of the Isle of Wight: with an attempt to develope Cuvier's idea of the classification of Pachyderms by the number of their toes. Quat J Geol Soc Lond. 4(1-2):103-141. doi: 10.1144/GSL.JGS.1848.004.01-02.21.

Perini FA, Oliveira JA, Salles LO, Moraes Neto CR, Guedes PG, Oliveira BO, Weksler M. 2011. New fossil records of Tapirus (Mammalia, Perissodactyla) from Brazil, with a critical analysis of intra-generic diversity assessments based on lower molar size variability. Geobios. 44(6):609-619. doi:10.1016/j.geobios.2011.02.005.

Rincón AD, Parra GE, Prevosti FJ, Alberdi MT, Bell CJ. 2009. A preliminary assessment of the mammalian fauna from the PliocenePleistocene El Breal de Orocual locality, Monagas State, Venezuela. Mus Northern Arizona Bull. 64:593-620.

Rincón AD, Prevosti FJ, Parra GE. 2011. New saber-toothed cat records (Felidae: Machairodontinae) for the Pleistocene of Venezuela, and the Great American Biotic Interchange. J Vert Paleontol. 31:468-478.

Rodrigues S, Avilla LS, Soibelzon LH, Bernardes C. 2014. Late Pleistocene carnivores (Carnivora: Mammalia) from a cave sedimentary deposit in northern Brazil. An Acad Bras Ciên. 86(4): $1641-1655$. 
Rodriguez SG, Soibelzon LH, Rodrigues S, Morgan C, Bernardes C, Avilla LS, Lynch E. 2013. First record of Procyon cancrivorus (G. Cuvier, 1798) (Carnivora, Procyonidae) in stratigraphic context in the Late Pleistocene of Brazil. J S Am Earth Sci. 45:1-5. doi:10. 1016/j.jsames.2013.01.004.

Roulin X. 1829. Memoir pour servir a l'histoire du tapir; et description dune espece nouvelle appartenant aux hautes regions de la Cordillere des Andes [Memoir to serve to tapir history; and description of a new species belonging to the high areas of the Andean Cordillera]. Ann des Sci Nat Zool Paris. 17:26-55.

Rusconi C. 1928. Nueva especie fósil de tapir de la Argentina Tapirus australis $\mathrm{n}$. sp. con una nota sobre Tapirus tarijensis [A new fossil tapir species from Argentina, Tapirus australis n. sp. with comments about Tapirus tarijensis]. In: Ameghino. Buenos Aires: Imprenta M. L. Rañó. p. 3-15.

Rusconi C. 1934. Sexta noticia sobre los vertebrados fósiles del puelchense de Villa Ballester [Sixth news of fossil vertebrates from the puelchense in Villa Ballester]. An Soc Cient Arg. CXVII: 177-186.

Scherler L, Becker D, Berger JP. 2011. Tapiridae (Perissodactyla, Mammalia) of the Swiss Molasse Basin during the OligoceneMiocene transition. J Vert Paleontol. 31(2):479-496. doi:10.1080/ 02724634.2011.550360.

Shipman P. 1981. Life history of a fossil: an introduction to taphonomy and paleoecology. Cambridge: Harvard University Press.

Simpson GG. 1945. Notes on Pleistocene and recent Tapirs. Bull Am Mus Nat Hist. 86:34-81.

Takai F, Arozqueta B, Mizuno T, Yoshida A, Kondo H. 1984. On fossil mammals from the Tarija Department, Southern Bolivia. Res Inst Evol Biol. 4:1-63.

Takai F, Mizuno T, Iwasaki Y, Tanaka K, Yoshida A. 1982. Tarija mammal bearing formation in Bolivia. Res Inst Evol Biol. 3:1-72.

Tong HW. 2005. Dental characters of the Quaternary tapirs in China, their significance in classification and phylogenetic assessment. Geobios. 38(1):139-150. doi:10.1016/j.geobios.2003.07.006.
Tonni EP. 1992. Tapirus Brisson, 1762 (Mammalia, Perissodactyla) en el Lujanense (Pleistoceno Superior-Holoceno Inferior) de la Provincia de Entre Ríos, República Argentina [Tapirus Brisson, 1762 (Mammalia, Perissodactyla) in the Lujanian (Late PleistoceneEarly Holocene) of Entre Ríos Province, República Argentina]. Ameghiniana. 29:3-8.

Ubilla M. 1983. Sobre la presencia de tapires fósiles en el Uruguay (Mammalia, Perissodactyla, Tapiridae) [About the presence of fossil tapirs in Uruguay (Mammalia, Perissodactyla, Tapiridae)]. Rev Fac Humanidades Ciencias. 1:85-104.

Ubilla M. 1996. Paleozoología del Cuaternario Continental de la Cuenca Norte del Uruguay: Biogeografía, Cronología y Aspectos Climáticoambientales. Programa de Desarrollo de Ciencias Básicas. Unpublished Doctoral Thesis, Universidad de La República, Uruguay. $232 \mathrm{pp}$.

Ubilla M. 2004. Mammalian biostratigraphy of Pleistocene fluvial deposits in northern Uruguay, South America. Proc Geol Assoc. 115(4):347-357. doi:10.1016/S0016-7878(04)80014-2.

Ubilla M, Rinderknech A. 2007. Fossil tapirs from Uruguay: a review. Ameghiniana Suplement. 44:42.

Wilson DE, Mittermeier RA. 2011. Handbook of the mammals of the world vol. 2, Hoofed mammals. Barcelona: Lynx. ISBN: 978-84-96553-77-4.

Winge H. 1906. Jordgundne og nulevende Hoydyr (Ungulata) fra Lagoa Santa, Minas Gerais, Brasilien. E Museo Lundii. 3: $1-239$.

Woodburne MO. 2010. The Great American Biotic Interchange: dispersals, tectonics, climate, sea level and holding pens. J Mammal Evol. 17(4):245-264. doi:10.1007/s10914-010-9144-8.

Woodburne MO, Cione AL, Tonni EP. 2006. Central American provincialism and Great Biotic Interchange. In: CarranzaCastañeda $\mathrm{O}$, Lindsay $\mathrm{EH}$, editors. Advances in late Tertiary vertebrate paleontology in Mexico and the Great American Biotic Interchange. Vol. 4. Universidad Nacional Autónoma de México, Instituto de Geología y Centro de Geociencias. Special Publication; p. $73-101$. 